\title{
Challenges in managing technological disasters in Cameroon: Case study of Cameroon's worst train Crash-the Eseka train disaster
}

\author{
Henry Ngenyam Bang ", Lee Stuart Miles, Richard Duncan Gordon \\ Disaster Management Centre, Bournemouth University Dorset, Talbot Campus, Fern Barrow, BH12 5BB, Poole, UK
}

\section{Introduction}

Railway transport is increasing globally but despite the adoption of diverse safety systems, accidents and fatalities continue to rise in many countries. Indeed, railway disasters have increased in developing countries since 1980, while the reverse is true in Europe. Statistics show that from 1970 to $2009,74 \%$ of railway disasters worldwide occurred in Africa, Asia, and South/Central America combined [1]. The trend also shows that since the mid-20th century, railway accidents worldwide have resulted in more people being non-fatally injured than fatally injured except in Africa where the relationship is almost equal [2].

The railway network of most African countries is a product of the colonial period, built cheaply (less than 4-inch gauge) inland from the ports and have not been upgraded for several decades [3,4]. Over the years, with insufficient investment and inadequate maintenance, the freight and passenger traffic has continued to increase, compromising safety with increased risk of accidents. In fact, increased traffic requires higher track expenditure maintenance because derailment risk decreases as the condition of the track improves [5].

A review of the causes of train accidents reveals that the main causes are infrastructure failures leading to derailment [5]; higher speeds and increased passenger traffic [2]; train driver distraction, inattention and non-compliance with train safety measures [6]. However, these attributes are worst in developing countries partly due to poor crash mitigation and safety systems $[2,6]$, and limited regulations or incomplete enforcement of existing rules [7].

Interestingly, research on technological hazards in many developing countries rarely focus on train accidents although it is responsible for one of the highest death rates in the transport sector. The few researches focus more on technology related train and railway safety, railway regulation and enforcement policies [2,6,7]. Moreover, whilst the prevailing disaster management (DM) practices of most developing countries are more reactive than proactive, managing response and recovery is ineffective [8]. Post-disaster management has not been given adequate research attention albeit the importance of proper crisis management in saving lives and livelihoods $[9,10]$. This article contributes in this direction, by examining the response and recovery to the worst train disaster ever to happen in Cameroon-the Eseka Train Disaster (ETD) that occurred on October 21, 2016.

We subscribe to the premise that technological hazards are caused by failures in the human system and their effects/impacts can be reduced through effective DM [11]. Hence, the aim of this article is to understand the management of technological disasters in Cameroon. To achieve the aim, two main objectives were identified: (1) to critically assess the response and recovery following the ETD that occurred in Cameroon and (2) Based on the findings, to identify lessons that can be learned from the management of the response and recovery, and provide recommendations for improvement.

The next section succinctly provides a background to train accidents in Cameroon. Section two is a brief review of technological hazards in Cameroon followed by the conceptual framework adopted by this research in section three. The methodology is discussed in section four while section five presents the events leading to the ETD. The research findings are presented and analysed in section six followed by a discussion section. The conclusion and recommendations is in section eight.

\section{Brief review of technological hazards in Cameroon}

Cameroon is prone to technological and natural hazard-induced disasters [8]. The Emergency Events Database (EM-DAT) of the Centre for Research on the Epidemiology of Disasters (CRED) reveals that from 1988 to 201841 technological disasters occurred in Cameroon causing 1542 deaths, 1272 injuries and affected 3061 people (see Table 1). Analysis from the database shows that of all transportation accidents, rail accidents cause the highest number of injuries (1050) and is second to fire hazards for the total number of people affected in all technological disasters in the country.

\footnotetext{
* Corresponding author.

E-mail addresses: hbang@bournemouth.ac.uk (H.N. Bang), lmiles@bournemouth.ac.uk (L.S. Miles), rgordon@bournemouth.ac.uk (R.D. Gordon).
} 
Table 1

Technological disasters in Cameroon from 1988 to 2017.

\begin{tabular}{|c|c|c|c|c|c|}
\hline Year & $\begin{array}{l}\text { Disaster } \\
\text { type }\end{array}$ & Occurrence & $\begin{array}{l}\text { Total } \\
\text { deaths }\end{array}$ & Injured & $\begin{array}{l}\text { Total }^{\mathrm{a}} \\
\text { affected }\end{array}$ \\
\hline 1988 & Other & 1 & 60 & ND & ND \\
\hline 1989-1994 & ND & & & & \\
\hline 1995 & Air & 1 & 74 & 4 & 4 \\
\hline 1995 & Water & 2 & 300 & DNA & ND \\
\hline \multicolumn{6}{|l|}{ 1996-1997 } \\
\hline 1998 & Rail & 1 & 120 & 150 & 150 \\
\hline 1999 & Road & 1 & 29 & ND & ND \\
\hline 2000 & Road & 3 & 51 & 70 & 70 \\
\hline 2001-2002 & ND & & & & \\
\hline 2003 & Road & 4 & 119 & 44 & 44 \\
\hline 2004 & DNA & & & & \\
\hline 2005 & Road & 2 & 24 & 12 & 12 \\
\hline 2005 & Water & 1 & 30 & ND & ND \\
\hline 2006 & Road & 3 & 55 & 12 & 12 \\
\hline 2006 & Water & 1 & 127 & ND & ND \\
\hline 2007 & Air & 1 & 114 & ND & ND \\
\hline 2007 & Road & 2 & 37 & 27 & 27 \\
\hline 2007 & Water & 2 & 32 & ND & 28 \\
\hline 2008 & Road & 2 & 27 & 16 & 16 \\
\hline 2008 & Water & 1 & 40 & ND & 6 \\
\hline 2009 & Rail & 1 & 5 & 300 & 300 \\
\hline 2009 & Water & 2 & 31 & ND & 5 \\
\hline 2010 & Fire & 1 & ND & 5 & 1755 \\
\hline 2010 & Road & 2 & 40 & ND & ND \\
\hline 2010 & Water & 1 & 24 & ND & ND \\
\hline 2011 & Road & 3 & 74 & 30 & 30 \\
\hline 2012-2015 & ND & & & & \\
\hline 2016 & Rail & 1 & 75 & 600 & 600 \\
\hline 2017 & Road & 1 & 20 & 2 & 2 \\
\hline 2017 & Water & 1 & 34 & ND & ND \\
\hline Total & & 41 & 1542 & 1272 & 3061 \\
\hline
\end{tabular}

a Total affected include the injured, without fatalities, including other aspects such as income loss, displacement and other illnesses directly or indirectly related to the incident such as stress exetera. ND No data.

Source: Adapted from Ref. [1].

Actually, a closer examination of technological hazards in Cameroon reveals the statistics held on the CRED/EM-DAT is inaccurate-more train accidents with potential dire long-term consequences for the survivors have occurred. Although an analysis of the EM-DAT/CRED database shows that 41 technological hazards from 1988 to 2018 caused 1542 deaths, 1272 injuries and affected 3061 people (see Table 1), the statistics is inaccurate. The database reports only three train accidents between 1988 and 2017. However, in 1998, there were 271 derailments with 37 occurring on the main Yaounde-Douala line resulting to several hundred deaths. Notable, was the Nsam train crash in Yaounde involving two petroleum tankers that killed around 120 people [3]. In 2009, train crashes caused 5 deaths and 300 injured [1]. After the ETD, from October 21, 2016 to December 8, 2017 four train accidents occurred in Cameroon-Ndokoti (Douala) on November 26, 2016; Elig-Edzoa (Yaounde) on March 8, 2017; near Makondo, about 87 miles west of Yaounde on July 26, 2017 and near Maboni Village (South West Region) on December 8, 2017.

The continuous growth of Cameroon's population (23.5 million as of 2016) and business transactions are increasing passenger and freight rail transport [3] (see Fig. 1). About 1.6 million passengers and 1.8 million tonnes of freight use the service annually [12] putting great pressure on the network, leading to an increase in railway accidents. The frequent train accidents pose a grave threat to Cameroon's transportation sector although the country has a sparse rail network-single railway track of $1104 \mathrm{~km}$ with $976 \mathrm{~km}$ operational and conceded to a single private operator: CAMRAIL [4] (see Fig. 2).

Cameroon has a 20-year concessioned (extended to 30 years in 2005) railway business model signed in 1999 by the government of Cameroon and CAMRAIL that involves the operation and management of rolling stock, rolling stock investment and operation and management of

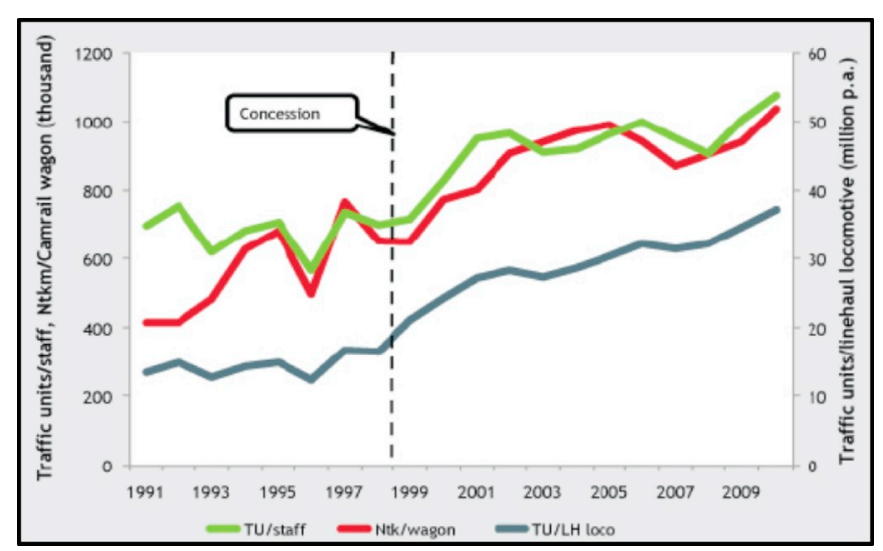

Fig. 1. Railway traffic in Cameroon from 1991 to 2011. Source: [3].

infrastructure. The Cameroon government owns $13.5 \%$ of the shares in CAMRAIL and has responsibility to finance the railway track rehabilitation while the Concessionaire, the Bollore Group that owns the bulk of the shares (77.4\%) was kept in charge of the operations and rolling stock financing, including maintenance of passenger carriages [4].

\section{Conceptual framework}

This article embraces a conceptual framework technique to provide focus and structure to this qualitative study [13]. The conceptual underpinning includes both pro-active and reactive strategies to DM called an integrated disaster management approach (IDMA) [14]. The IDMA has been conceptualised into the traditional DM process that consists of four complementary phases-mitigation and preparedness (pro-active or risk-reduction phase) and response and recovery (reactive or post-disaster phase) commonly known as the DM cycle (see Fig. 2).

The adapted framework in Fig. 2 shows key activities for effective $\mathrm{DM}$ at the different phases obtained from in-dept review of organisational DM manuals and training documents; government DM policies, frameworks, plans and programmes and academic/research articles, including books on DM [11,14-25]. Furthermore, the framework blends contemporary strategies, techniques and good DM practices in DM such as multilevel, multi-dimensional and multidisciplinary cooperation and collaboration; enhancing coordination and integration of stakeholders' action through good communication and efficient exchange of relevant and reliable information; ensuring that appropriate enabling policy, capacity building and resource mechanisms are in place; implementing the DRM process from the national level to the community level and achieving effective disaster reduction and response through decisions based on reliable disaster risk information [26].

Although the conceptual framework shows the standard DM model with four phases, this research focuses on the response and recovery phases of the ETD. However, operationally, all the phases complement each other. Detailed analysis of all the phases, inclusive of risk reduction (mitigation and preparedness) is beyond the analysis of this article, albeit it informs the causes of the ETD (see Section 7).

Response is conceptualised in this article as the provision of emergency services and public assistance during or immediately after a disaster in order to save lives, reduces health impacts, ensure public safety and meet the basic subsistence needs of the people affected. Recovery is the restoration and improvement where appropriate, of facilities, livelihoods and living conditions of disaster-affected communities, including efforts to reduce disaster risk factors [27].

\section{Methodology}

This is a case study research that adopts an empirical qualitative and descriptive approach employing strategies such as thematic and 


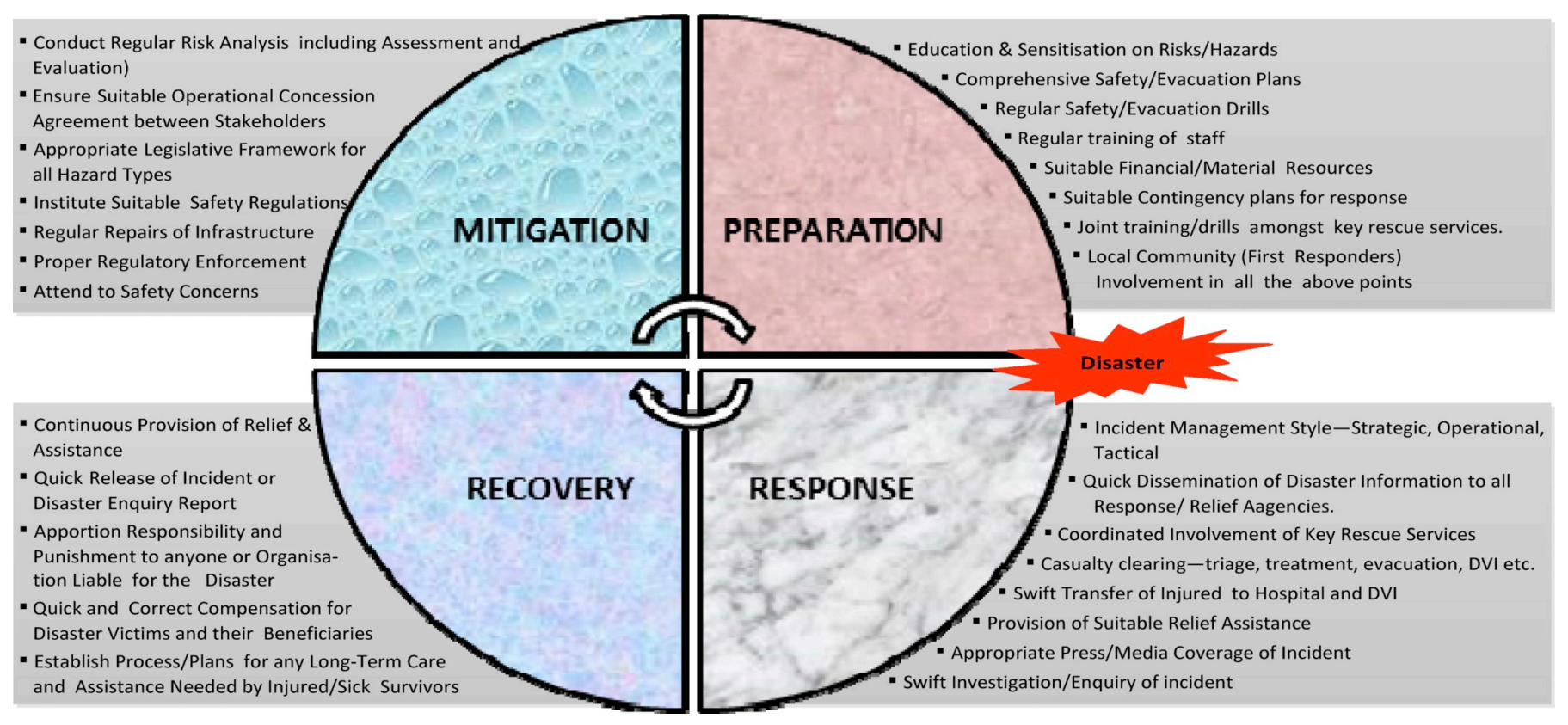

Fig. 2. The DM Cycle showing key activities in the management of disasters, Source: Authors.

narrative analysis. This approach is central to understanding institutional practices and the behaviour of disaster authorities and offers flexibility to the researcher to gain better insight into the phenomenon under study, and a greater ability to give an in-dept analysis [28]. Indeed, case studies help to bring an understanding of complex issues that adds strength to the understanding of a social phenomenon [29].

The article was inspired by another research. While the corresponding author was conducting interviews for another related research on disaster risk reduction in Cameroon in 2017, the respondents, mainly mid-top level DM stakeholders repeatedly used the ETD (which occurred a few months earlier) as evidence to elucidate their responses on resilience to technological disasters in the country. Due to the rich data being obtained on the ETD, the researcher reviewed the research strategy and decided to probe further into the ETD.

Technical reports, official documents and interviews comprised sources of primary data. At the time of the research, the ETD was just 6-7 months old so very few documents/reports were available on the incident. However, there were incomplete reports that the research could not obtain because such were considered sensitive and required authorisation from senior management. The researcher was told to be patient and have access to them when they are officially released. Indeed, several months/years after the incident, the government has granted access-via government websites, to selected reports/documents on the ETD. Technical reports and official documents were obtained from diverse sources-for example [4,30-38].

Semi-structured interviews (face-to-face and telephone) were done between March and April of 2017 concerning the management of the ETD — the case study of this research. Initially a purposeful sampling technique was used to identify six, eight and nine DM practitioners who were involved in the tactical, strategic and operational management of the ETD respectively from different government agencies/ministries. Of the six managers with tactical functions contacted at the national level, four were involved in the ongoing investigation into the ETD and preferred not to comment. One recommended a colleague who accepted (including the two initially contacted) to be interviewed under conditions of anonymity. Four respondents from the emergency services with strategic DM responsibilities at the regional level were interviewed through a snowballing technique, suggested by their peers who were unavailable for interviews due to other commitments. Since the researcher's time in the Cameroons was limited, a local research assistant interviewed 5 of the 9 personnel involved in the operational response to the ETD. Therefore, a total of twelve interviews were conducted-three, four and five at the national, regional and local levels, respectively. The interview process was guided by ethical principles and the opportunity of gaining access to people who can supply rich information [39,40]. Respondents provided in-dept information on a broad range of issues based on question themes that focused on activities relating to their specific roles, responsibilities and experiences during the response and recovery of the ETD including how they perceive the overall management of the incident.

To enhance the validity of the research, empirical data was triangulated with information sources obtained from reports, policy/technical documents held by the government, private, corporate and International agencies and organisations, academic journals and newspaper articles. In fact, the latter constitute a vital source of information as all aspects of the incident management is in the public interest and has been covered extensive by both the government and private press.

Considering our professional and operational activities that revolve daily around academic and practical aspects of DM, we are conscious to be reflective on our personal position within and relative to this study to minimise any prejudices, assumptions and bias in the data collection and analysis [41]. The adapted IDMA (see Section 2) guided the thematic data analysis.

Ethical considerations underpin empirical data collection in this research with informed consent, anonymity and confidentiality adopted as key principles. Participation was on a voluntary basis with verbal consent obtained from the respondents after details of the research (purpose, process, participants choice/voluntary participation, outcome etc) had been explained. Potential disaster management stakeholders initially contacted who were sceptical to participate were not coerced. The anonymity and confidentiality of those who consented to participate was guaranteed. Digitally recorded interviews were done only with the permission of respondents, and there was mutual agreement with some that recorded interviews be removed once the data had been transcribed and analysed [28,42].

\section{The Eseka train accident}

On October 21, 2016, an inter-city train (No. 152) travelling from Cameroon's capital city (Yaounde) to the economic capital (Douala) had 
a fatal accident at about 12.30 p.m. in Eseka about 75 miles from Yaounde (see Fig. 3). When the accident happened, the train had 17 carriages and about 1300 passengers on board.

The train derailed at a bend causing four carriages to overturn (see Fig. 4). At the time of the accident, the train was overloaded with 700 more passengers than its normal capacity of 600 . More than 200 people died and about 1000 were injured [43] although the official government report said 81 dead and 801 injured [44,45].

The Presidency set up a commission of enquiry (COE) into the ETD on October 25, 2016 under the auspices of the Prime Minister (PM). The COE was assigned the following tasks; determine the causes of the accident; determine who is to be blamed for the accident; assess the disaster response in terms of how the incident was managed, including assistance to the victims and to propose any helpful recommendations and propose measures aimed at reducing risks of similar disasters in the future [33,34].

The finding of the COE was released seven months later-May 23, 2017. The report stated that CAMRAIL had "total and entire responsibility" for the crash and was mainly to blame for the accident. It mentioned five main reasons for the ETD: (i) CAMRAIL's non-observance of safety rules as the main cause of the accident; (ii) over speeding-the train was travelling at $96 \mathrm{~km} / \mathrm{h}(60 \mathrm{mph})$ on a rail section that has a lower speed limit of $40 \mathrm{~km} / \mathrm{h}(25 \mathrm{mph})$ and in an area with steep slopes and several sharp bends; (iii) Overloading - the train was carrying 1300 passengers rather than its normal capacity of 600 ; (iv) defective braking system-13 of the 17 carriages on the train had malfunctioning braking systems; (v) there was no proper pre-departure inspection of the rake's braking system in Yaounde and (vi) CAMRAIL's administrators ignored warnings expressed by the train driver on points (v). In addition, the enquiry report mentioned that the response of the emergency services was inadequate and/or poor.

A key recommendation of the COE was that “... the capacity of Government services to conduct rescue operations during disasters must be enhanced for greater responsiveness, coherence and fluidity and for better victim management'. In response to the COE's report, the government ordered the enhancement of the national major disaster and risk prevention and management system through (i) mainstreaming of terrorist act occurrences, (ii) better ownership by stakeholders of their respective roles and the chain of command, and (iii) regular conduct of full-scale drills [34].

\subsection{Events leading up to the accident}

Prior to the train accident, heavy rainfall and landslides on the early hours of Friday, October 21, 2016 had caused a bridge to collapse over the Doupe River (see Fig. 5) at Manyai, 43 miles from Yaounde, along the busy Yaounde-Douala highway, which has the heaviest traffic in the country. The bridge collapsed and cut movements between the two cities leading to a considerably high passenger built. The stranded passengers sort alternative ways of transportation and decided to use the next easily available and affordable means that is by rail. Consequently, the number of passengers travelling by rail increased tremendously. In response, the management of the rail network, CAMRAIL (also known as Cameroon Railways) added more carriages to the Yaounde-Douala intercity trains.
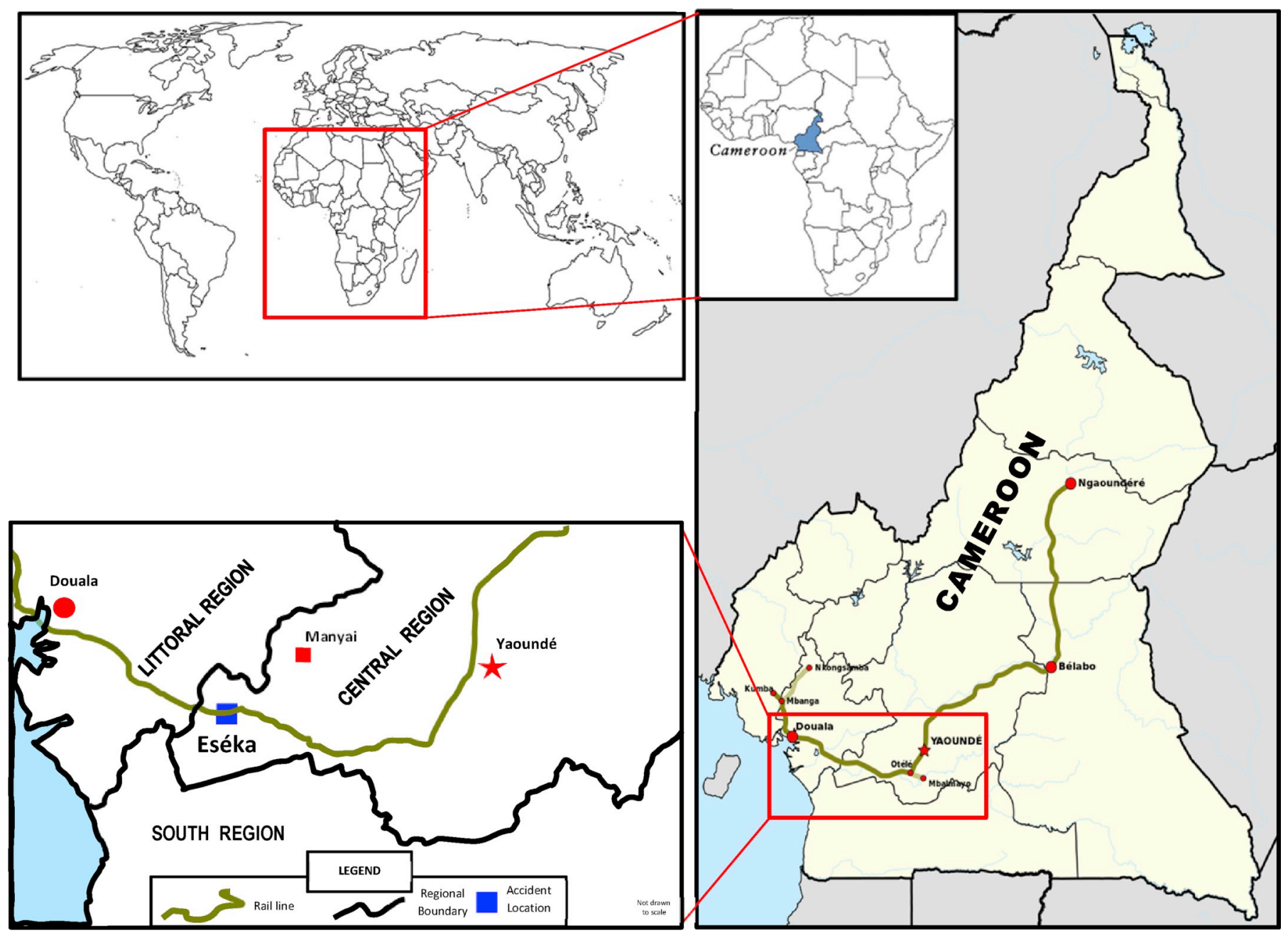

Fig. 3. Location of Eseka along Cameroon's rail network. Source: Adapted from Ref. [12]. 


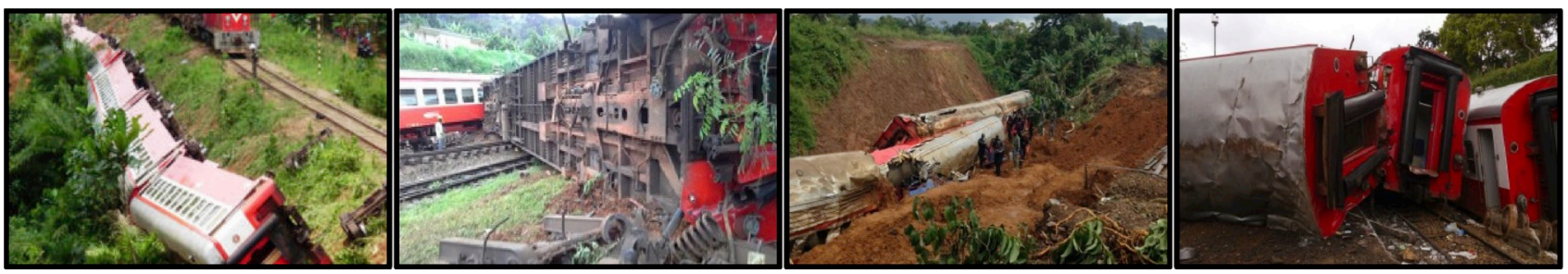

Fig. 4. Derailed trains during the Eseka train accident. Source: Various courtesy of [46,47].

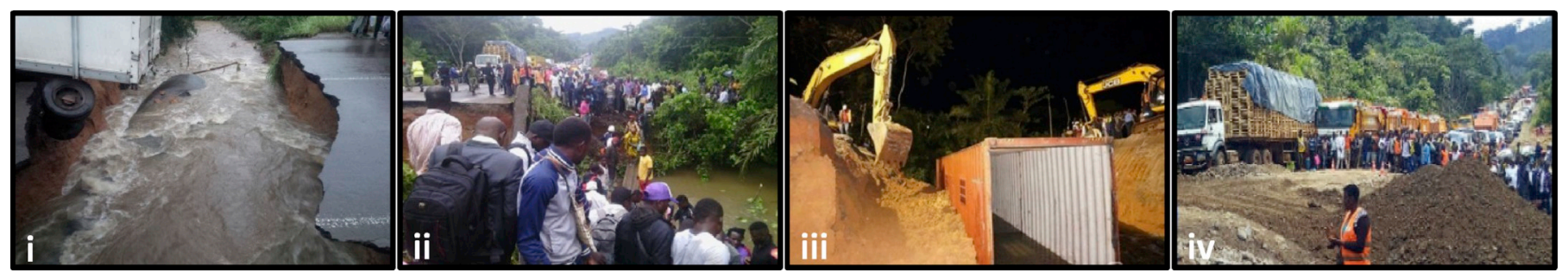

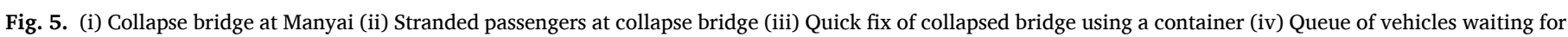
the bridge to be fixed. Source: Various- $[47,48]$.

\section{Research findings}

This section analyses the management of the ETD with focus on the response and recovery. In fact, one of the tasks assigned to the COE following the accident was to assess the disaster response in terms of how the incident was managed, including assistance to the victims.

\subsection{Response to the ETD}

\subsubsection{Crisis response coordination}

The management of the immediate aftermath of the ETD left much to be desired. The ETD occurred when Cameroon's President had been abroad for three weeks. All respondents ( $N$ 12) believe the president succumbed to pressure from the Cameroonian diaspora and returned home on October 23, two days after the disaster. He sent condolence messages to the bereaved families via his Facebook account, and announced a government led COE to determine the cause of the disaster. However, respondents thought he should have done more. According to a senior administrator " ......upon his return, he did not bother to visit the disaster site or see the victims and evaluate what had happened considering this was the worst train accident in the country".

All the respondents at the regional and local levels ( $\left.\begin{array}{ll}\mathrm{N} & 9\end{array}\right)$ informed the research that the first opportunity to tell the nation about governments' immediate actions to resolve the crisis was missed when the PM visited Eseka the day after the accident but refused a request from the traditional leaders of the region to brief them and the press on government's actions [47].

Furthermore, an inter-ministerial delegation led by the Ministers of Transport and Public Health visited the accident site shortly after the disaster. While respondents at the national level $\left(\begin{array}{ll}\mathrm{N} & 3\end{array}\right)$ said this was appropriate action to apprise the situation, they were critical of the ministers making unilateral decisions to rush to the scene without consulting with stakeholder ministries and the Directorate of Civil Protection (DCP) - the nodal agency responsible for coordinating DM activities in Cameroon. The Minister of public health announced that his ministry would oversee managing the accident scene [30]. However, all the interviewees ( $\mathrm{N}$ 12) intimated minimal cooperation and coordination on the scene with different ministries/agencies adhering to their chain of command rather than adopting a coordinated approach.

For example, the research was informed that the Ministry of Territorial Administration and Decentralisation (MTAD) set up two crisis committees; one in Eseka under the auspices of the Senior Divisional
Officer (SDO) of Eseka and the other in Douala, the train's destination. The committees handled managing information at the scene of the accident and to ensure the safe transfer of the ETD survivors to Douala. The committee in Eseka ran an ad-hoc Emergency Operations Centre (EOC) that supplied a toll-free number for those affected to enquire about relative involved in the disaster. On the other hand, CAMRAIL also set up a crisis centre at the Yaounde and Douala railway stations and issued a hotline number (699 1018 10) for enquiries [36].

All the Respondents ( $N$ 12) confirmed the rescue operation were plagued with numerous problems. 3 out of the 4 respondents at the regional level and all local respondents informed the research that coordination of both EOCs had issues because their information was not synchronised. They were also concerned that call operators were few and spoke French only. This posed problems to the English-speaking Cameroonians who found it difficult to communicate with the operators. The importance of cooperation, coordination and control for effective crises management cannot be over-emphasised [10,27] (see Fig. 2).

\subsubsection{Search and rescue (SR)}

The rescue operation was very slow and chaotic. All responders acknowledged the vital role played by the local population (first responders) to save lives in the immediate aftermath of the accident. They said prior to the arrival of emergency services on the scene, local people had rescued most of survivors (see Fig. 6). This response is corroborated with newspaper reports. For example, a 32-year-old local man, Franklin, rescued injured people and removed about 50 dead bodies from the wreckage [43]. In addition, the regional and local interviewees ( $\left.\begin{array}{ll}N & 9\end{array}\right)$ acknowledged that the Eseka residents who arrived the scene first provided local first aid and traditional treatment to the wounded while waiting for the emergency services. This was confirmed by press reports [49].

According to local respondents, the Cameroon Red Cross (CRC) was one of the first NGOs to arrive the scene. The CRC deployed 66 emergency responders who provided first aid to 561 injured passengers within $48 \mathrm{~h}$ and retrieve 55 dead bodies from the wreckage [36].

The first government emergency services reached the scene late in the evening and according to the local respondents ( $\mathrm{N}$ 5), several dead bodies and injured passengers had been trapped in the wreckage for several hours before they arrived. Indeed, injured passengers were trapped in the wreckage in some cases for up to $24 \mathrm{~h}$ without help before some died [49]. This is partly because the first rescuers did not have the 


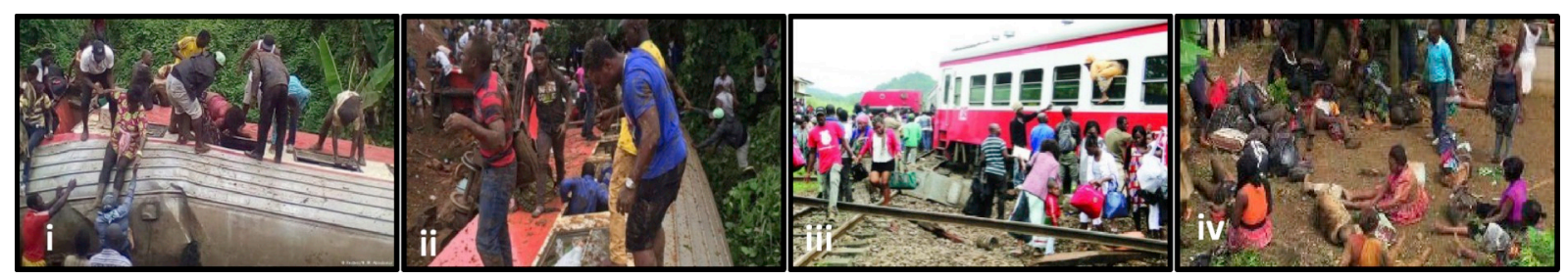

Fig. 6. (ii) First responders (public) rescuing trapped passengers (iii) Woman desperately tries to get out of derailed train (iv) rescued injured passengers sit helpless on the ground. Source: Various courtesy of Reuters, AFP/GETTY images.

appropriate equipment to remove trapped people/bodies from the wreckage [36]. The emergency and security services deployed to the scene were the National Fire Service (NFS), Police, Gendarmes, a medical team, CAMRAIL's security and the Army Engineers who played a vital role in the rescue operation.

Findings also uncovered delays in the rescue operation. Removal of the damaged/derailed carriages only started on October 22nd-more than 24 hrs later. Respondents ( $\mathrm{N}$ 10) affirmed the Army Engineering Corps used cranes to remove the damaged carriages in an operation that lasted three days. Indeed, 14 people were still trapped in the wreckage on the night of the day the accident occurred and on October 22, 23, and 24; 15,7 and 12 bodies respectively were recovered from the wreckage of the damaged carriages [51]. All respondents ( $N$ 12) were unanimous that the slow recovery pace compromised the survival of some trapped victims. In an interview granted to the French newspaper - Le Monde Afrique News after the ETD, the supervisor of the recovery operation said although the priority was to extract the bodies trapped, the challenge was to get to them without damaging the carriages [43]. When the research recounted this statement to the respondents, 1 out of the 3 respondents with tactical functions and all the regional and local respondents ( $\mathrm{N} 9$ ) interpreted it as implying the military rescue team was trying to minimise damage to the train rather than expediting the removal of potential survivors, hence the slow pace of the rescue/recovery operation.

\subsubsection{Medical assistance and mass casualty handling}

Research findings reveal several difficulties in the provision of medical assistance. Eseka is small town in the Nyong-et-Kelle Division of the Central Region (Fig. 3) and has a district hospital that lacks sufficient medical facilities. Hundreds of survivors and dead people were taken to the Eseka District Hospital but the hospital was quickly overwhelmed because it lacked a blood bank, had limited anti-tetanus serum, had only 60 beds for patients, mortuary space for only 15 bodies and quickly ran out of medication to treat the sick. Furthermore, the poor state of the road hampered efforts to transport medical materials to the hospital-92\% of respondents ( $\mathrm{N}$ 11) [30, 43]. The Ministry of Health supplemented the medical equipment of the Eseka hospital to facilitate treatment of the victims [31]. While this action is applauded, the government should always ensure hospitals are well-equipped to handle emergencies.

Due to lack of space at the Eseka District Hospital, most of the injured and dead were transported to other hospitals in the Central and Littoral Regions. Triage of the injured took place in a temporary health facility created at the Yaounde train station [30] although this should happen at the scene of the accident. The deceased/injured transported to Yaounde were taken several health facilities-Yaounde Emergency Centre, Central Hospital, University Teaching Hospital, Police Medical Centre and Military hospital. Those taken to Douala were accommodated at health facilities there including the Pouma, Laquintinie, General, Gyno-obstetrics and Military hospitals, including the Muna and IDIMED Clinics $[30,31,51]$. Some hospitals ran out of shortage of blood to treat the injured. Indeed, the Cameroon National Order of Physicians said the emergency required at least 20,000 sachets of blood [36]. To this effect, the Ministry of Health appealed to the public to donate blood [52]. The president promised that the state would take care of all the medical bills [33].

\subsubsection{Evacuation of the injured and the dead}

The evacuation of the injured passengers from Eseka was not a fast and smooth process. According to the regional and local interviewees (N 9), bad roads compounded the evacuation effort. Indeed, the wreckage had to be removed from the rail track before trains could evacuate the victims to other hospitals. Local respondents ( $\left.\begin{array}{ll}N & 5\end{array}\right)$ mentioned that many wounded survivals were dispatched to hospitals in Douala and Yaounde two days after the ETD, many in critical condition. For instance, between 60-70 dead bodies and 50 injured people, some unconscious, arrived the train station in Yaounde two days after the accident. In fact, the Governor of the Littoral Region confirmed that more than 200 victims were sent to Douala and some died upon arrival at the hospitals there [50]. These accounts indicate that many lives were lost due to delays in evacuating the injured.

\subsubsection{Casualty tracking and disaster victim identification (DVI)}

DVI is major limitation in the response to the ETD. Research evidence (from 8 out of the 9 regional/local respondents) suggests the emergency services did not implement formal procedures to recover, identify and track the deceased and human remains sent to hospitals in the region. Consequently, people flooded hospitals in Yaounde and Douala in a blind search for their relatives who boarded the train. For example, a man (Mustapha Abbo) lost the sister in the accident but could not trace the corpse [49]. Similarly, a 42-year old man found the dead body of his sister's son in Yaounde after searching in vain in Douala [49]. There was no DVI service to provide accurate information about the whereabouts of the injured and dead.

The Ministry of Health sent out a press release stating that 68 bodies were taken to mortuaries in Yaounde hospitals. The public were to fulfil the following conditions before collecting dead relatives: at least three relatives were to confirm/identify the dead, provide their Identity cards, and proof of family relation - birth/marriage certificates [32].

Furthermore, interview data from all national and regional interviewees ( $\mathrm{N}$ 7) suggests some passengers could not be found/traced more than one year after the ETD. For example, a prominent Cameroon Lawyer (Barrister Dorette Dissake), who sat on seat number 54C in carriage No 152 has not been found (dead or alive) more than one year after the incident [53]. The husband told the press that: "My wife was in this train; she was sitting in first class. When the train derailed, some people in his carriage survived. But she is totally missing ... If she is dead, where is her body?" [54]. In addition, Mr Lesieur David Mekem has also been searching for his son (Romial Tedonzong) since October 21, 2016 [55]. The government also confirmed missing victims from the ETD (see Section 6.2.1).

Since all the local responders ( $\mathrm{N} \quad 5$ ) confirmed that body parts were found at the scene of the accident-see also [36, 43], these might have belonged to some missing passengers. All respondents were unsure whether appropriate techniques were used to identify the body parts. Forensic techniques would certainly link dead victims, including body parts, with their relatives.

Interestingly, the findings of the COE to identify the cause of the ETD 
and that to compensate the victims did not mention the exact number of passengers in the train at the time of the accident [44]. Moreover, Governments' reaction to the COE's report did not mention whether the search for the missing passengers will continue or actions will be taken to identify/trace their dead bodies. Research attempts to find out if the train had a passenger manifest proved to be futile. $100 \%$ of the respondents $(\mathrm{N}$ 12) alleged it was a common practice to issue train tickets without documenting the names of the passengers. Without a clear idea of the number and names of passengers who boarded the train that faithful day we may never know the exact number and nationalities of fatalities. The Minister of Foreign Affairs, however, said a French national was killed and another one wounded [50].

\subsection{Recovery}

\subsubsection{Compensation for victims}

After the ETD, both CAMRAIL and the Government promised to provide financial assistance to the victims and/or their beneficiaries. CAMRAIL promised to compensate each family's victim with 1 million FCFA (Franc de la Communaute Financiere d'Afrique) equivalent to US\$ 1779. However, several families have not been paid. Interviews and press reports reveal that CAMRAIL was using unethical ways to manoeuvre the victims to either not compensate them or provide discounted compensation packages far lower than promised. According to $75 \%(\mathrm{~N} 9)$ of the respondents and [56], many victims who have been compensated were offered reduced amounts, which they accepted because of poverty. For instance, one victim requested 51 million FCFA ( US\$ 91, 445) but was paid only 4 million FCFA( US\$ 7172); another victim fractured his right hand, was operated at his testicles, constantly bled from his nose and had problems with his nerves but was awarded just $5 \%$ of what he requested, which he refused [43]. It was alleged that CAMRAIL was encouraging victims not to use lawyers, claiming they were blocking the compensation process [57]. Around 83\% (N 10) of the interviewees were keen to point out that without adequate compensation, disaster victims in poor countries like Cameroon are left with undesirable long-term consequences for the rest of their lives.

The government also pledged one billion FCFA ( US $\$ 1.8$ billion) as supplementary assistance to the victims and their rightful claimants [33]. To this effect, the PM set up a compensation commission that published a list of potential 888 beneficiaries on October 21, 2017. Analysis of the list reveals that 801 survivors sustained body injuries and can prove temporary disability of at least one day, 81 people died (4 corpses unidentified) and 7 people were missing [44]. Details of how the compensation will be shared is not known but our calculation indicates that if all survivors and families of the dead/missing were to be compensated equally, each will receive 112,486 FCFA ( US\$ 197.5), a small amount indeed.

\subsubsection{Blame avoidance}

Findings reveal CAMRAIL and the government tried desperately to divert culpability for the ETD. When the accident happened, the Board Chair of CAMRAIL released a public statement denying the company was responsible for it. It was also alleged that a CAMRAIL worker attempted to steal the train event recorder and falsify the data relating to the number of wagons, tonnage and stop brake weight, which can reveal the true condition of the train prior to the accident. Purportedly, also, a CAMRAIL technician who was in the train at the time of the accident has received threats to stop him from revealing the real cause of the accident [58].

Furthermore, research evidence suggests that the Minister of Transport instructed CAMRAIL officials to add more carriages to the trains in order to accommodate passengers that flooded the Yaounde train station following the collapse of the bride at Manyi [59]. Not surprisingly, the Minister denied the allegations during an interview with Canal 2 TV stating that CAMRAIL unilaterally took the decision to add the carriages [60]. He publicly blamed the train driver for the accident. The train driver only availed himself after revealing that he raised safety concerns about the train before departing from Yaounde but was ignored by his manager [34]. Attempts to avoid and shift blame onto others is a common characteristic of Cameroon's DM [61].

Although all national level respondents and $78 \%(\mathrm{~N} \quad 7)$ of the regional/local respondents acknowledged that CAMRAIL's shares blame for the accident for adding defective carriages, around 34\% of the interviewees ( $\mathrm{N}$ 4-2 national and regional), questioned the fairness of the enquiry that indicted CAMRAIL alone considering the government has stakes in the company $[3,4]$. We would argue that the blame avoidance is due to incompetency and policy failure rather than incapacity [61].

\subsubsection{Implications for CAMRAIL}

The government reacted to the findings of the ETD enquiry by outlining the following actions: to review the concession agreement with CAMRAIL that authorised the corporation's operations in Cameroon; to initiate a dialogue with CAMRAIL about a greater state involvement in the corporation especially on social issues, notably passenger transport; to set up a temporary company responsible for maintaining and modernising the railway network [34]. Whether these actions will actually happen is still to be seen.

In addition, all respondents ( $\mathrm{N}$ 12) were aware that the government, disaster survivors and their relatives have sued CAMRAIL - the government filed a lawsuit against CAMRAIL in the court of first instance in Douala on September 28, 2017. CAMRAIL has also been sued in France by the families of two French citizens involved in the accident. The multiple charges levied against CAMRAIL range from manslaughter, dangerous activities, recklessness, negligence and missing person [43, 62,63]. CAMRAIL disputes some of the charges, citing, for example, design flaws in new trains purchased from China in 2014-an allegation the manufacturer refused [64]. Suing CAMRAIL sends a strong signal that companies must take full responsibility for their activities.

Furthermore, the ETD has resulted to administrative changes in CAMRAIL. The General Manager of the Company was sacked and replaced on June 9, 2017. The Chair of the board of directors was also replaced with a senior civil servant from the PM's office $[59,65]$. All the interviewed senior civil servants at the national level $(\mathrm{N} \quad 3$ ) believe the appointment of the Chairman of the Board of Directors is a government strategy to have a greater representation and influence in CAMRAIL's management.

Table two highlights the key response and recovery activities from the research findings, problems identified, or lessons learned and key recommendations.

\section{Discussion}

Apart from commercial aviation, railways are the most safe and sustainable form of transport [66]. However, this is not the case in many developing countries like Cameroon where railway transportation is preferred due to its low cost. As the ETD has shown, train crashes, although less frequent than automobile accidents, are macabre, often fatal, and more likely to cause fatalities or serious health problems on victims such as amputations or paralysis $[67,68]$.

The findings of the COE mentioned operational and safety issues that caused the ETD and blamed CAMRAIL solely for the incident. The report, which undermined government's role in the incident, is biased albeit not surprising since the COE was set up by the government. From the COE's report, one can establish a link between infrastructure, operations, maintenance and safety. Since the government has stakes in CAMRAIL with the responsibility to finance the railway track rehabilitation [4], an independent COE should have been set up so that all the stakeholders involved are treated fairly, lawfully, and the timeline/budget for the enquiry is maintained. An independent COE is ideal to engage in a worthwhile fact-finding exercise of polity formulation and structural reform in Cameroon's railway industry. The trigger for an 
Table 2

Activities, problems identified and lessons learned/recommendations from managing the response and recovery of the ETD.

\begin{tabular}{|c|c|c|}
\hline $\begin{array}{l}\text { Response and } \\
\text { Recovery Activities }\end{array}$ & $\begin{array}{l}\text { Lessons Learned/Problems } \\
\text { Identified }\end{array}$ & Recommendations \\
\hline \multirow[t]{7}{*}{$\begin{array}{c}\text { Crisis Response } \\
\text { Coordination }\end{array}$} & $\begin{array}{l}\text { The legal authority of the } \\
\text { DCP to coordinate } \\
\text { incidents/disasters in } \\
\text { Cameroon was not } \\
\text { respected. }\end{array}$ & $\begin{array}{l}\text { DM stakeholders should } \\
\text { be educated to recognise } \\
\text { and respect the DCP as } \\
\text { the central agency } \\
\text { responsible for } \\
\text { coordinating incidents/ } \\
\text { disasters. }\end{array}$ \\
\hline & $\begin{array}{l}\text { Government ministers } \\
\text { unilaterally visited the } \\
\text { crisis scene without a } \\
\text { central coordination. }\end{array}$ & $\begin{array}{l}\text { Allied DM ministries/ } \\
\text { agencies should first } \\
\text { liaise with the DCP after } \\
\text { incidents/disasters prior } \\
\text { to visiting disaster scenes. }\end{array}$ \\
\hline & $\begin{array}{l}\text { There was chaos at the } \\
\text { accident scene without a } \\
\text { clear idea of the agency } \\
\text { leading the operations. }\end{array}$ & $\begin{array}{l}\text { The government should } \\
\text { establish a clear incident } \\
\text { command structure for } \\
\text { major incidents and } \\
\text { educate the security } \\
\text { services. }\end{array}$ \\
\hline & $\begin{array}{l}\text { There was duplication of } \\
\text { functions by emergency } \\
\text { services at the accident } \\
\text { scene. }\end{array}$ & $\begin{array}{l}\text { The main emergency } \\
\text { services should be trained } \\
\text { on their specific } \\
\text { responsibilities in a } \\
\text { unified incident response. }\end{array}$ \\
\hline & $\begin{array}{l}\text { CAMRAIL and the } \\
\text { government were } \\
\text { running different ad-hoc } \\
\text { uncoordinated EOCs. }\end{array}$ & $\begin{array}{l}\text { A national EOC should be } \\
\text { established under the } \\
\text { DCP with authority to } \\
\text { manage information } \\
\text { during crisis situations. }\end{array}$ \\
\hline & $\begin{array}{l}\text { The ad-hoc EOCs has few } \\
\text { operatives that were not } \\
\text { bilingual. }\end{array}$ & $\begin{array}{l}\text { Enough trained and } \\
\text { bilingual operatives } \\
\text { should be recruited to } \\
\text { work in EOCs that are } \\
\text { well equipped. }\end{array}$ \\
\hline & $\begin{array}{l}\text { Operational inter-agency } \\
\text { coordination and cooper- } \\
\text { ation was poor. }\end{array}$ & $\begin{array}{l}\text { Regular incident } \\
\text { management drills } \\
\text { involving the emergency } \\
\text { services should be } \\
\text { conducted. }\end{array}$ \\
\hline \multirow[t]{3}{*}{$\begin{array}{l}\text { Search and Rescue } \\
\quad \text { (SR) }\end{array}$} & $\begin{array}{l}\text { First responders were } \\
\text { members of the local } \\
\text { community with no first } \\
\text { aid skills. }\end{array}$ & $\begin{array}{l}\text { Local communities along } \\
\text { the railway lines should } \\
\text { be provided with basic } \\
\text { first aid and search and } \\
\text { rescue training. }\end{array}$ \\
\hline & $\begin{array}{l}\text { The emergency services } \\
\text { reached the accident } \\
\text { scene several hours after } \\
\text { the incident. }\end{array}$ & $\begin{array}{l}\text { The emergency services } \\
\text { should have unlimited } \\
\text { access to logistics that can } \\
\text { enable swift deployment } \\
\text { to incident sites. }\end{array}$ \\
\hline & $\begin{array}{l}\text { The operation to remove } \\
\text { the wreckage, trapped } \\
\text { victims and fatalities was } \\
\text { slow, probably because } \\
\text { rescuers were cautious } \\
\text { not to seriously damage } \\
\text { the wreckage. }\end{array}$ & $\begin{array}{l}\text { Major rescue operations } \\
\text { should focus on saving } \\
\text { lives rather than prevent } \\
\text { damage to property in the } \\
\text { process. Property can be } \\
\text { replaced but lives lost } \\
\text { cannot be replaced. }\end{array}$ \\
\hline \multirow[t]{2}{*}{$\begin{array}{l}\text { Medical Assistance } \\
\text { and Mass Casualty } \\
\text { Handling }\end{array}$} & $\begin{array}{l}\text { The Eseka District } \\
\text { Hospital lacked basic and } \\
\text { enough first aid kits to } \\
\text { treat the wounded. } \\
\text { Medical staff deployed } \\
\text { from Yaounde to the } \\
\text { accident scene lacked the } \\
\text { necessary equipment and } \\
\text { medicine to treat the } \\
\text { injured. }\end{array}$ & $\begin{array}{l}\text { All hospitals should have } \\
\text { abundant reserves of } \\
\text { basic first aid kits for } \\
\text { emergency treatment. } \\
\text { The government should } \\
\text { review its contingency } \\
\text { plans for health } \\
\text { emergency assistance } \\
\text { with the provision of } \\
\text { appropriate resources } \\
\text { and training of personnel. }\end{array}$ \\
\hline & $\begin{array}{l}\text { Triage of injured } \\
\text { passengers was done } \\
\text { upon arrival in Yaounde. }\end{array}$ & $\begin{array}{l}\text { Triage of injured } \\
\text { passengers should be } \\
\text { done at the accident } \\
\text { scene to prioritise victims } \\
\text { in need of urgent } \\
\text { treatment. }\end{array}$ \\
\hline
\end{tabular}

Table 2 (continued)

\begin{tabular}{|c|c|c|}
\hline $\begin{array}{l}\text { Response and } \\
\text { Recovery Activities }\end{array}$ & $\begin{array}{l}\text { Lessons Learned/Problems } \\
\text { Identified }\end{array}$ & Recommendations \\
\hline $\begin{array}{l}\text { Evacuation of the } \\
\text { injured and dead }\end{array}$ & $\begin{array}{l}\text { Poor road conditions } \\
\text { delayed transportation of } \\
\text { the injured to other } \\
\text { hospitals. }\end{array}$ & $\begin{array}{l}\text { Where accessibility is a } \\
\text { problem, helicopters } \\
\text { should be used to } \\
\text { transport injured } \\
\text { passengers swiftly to } \\
\text { hospitals. }\end{array}$ \\
\hline \multirow[t]{3}{*}{$\begin{array}{l}\text { Casualty Tracking } \\
\text { and Disaster } \\
\text { Victim (DVI) } \\
\text { Identification }\end{array}$} & $\begin{array}{l}\text { Casualty tracking of the } \\
\text { injured/dead was } \\
\text { extremely poor resulting } \\
\text { to a blind search for } \\
\text { victims. }\end{array}$ & $\begin{array}{l}\text { The government should } \\
\text { put in place clear } \\
\text { procedures/guidelines } \\
\text { for victim identification } \\
\text { and tracing the injured/ } \\
\text { dead during disasters. }\end{array}$ \\
\hline & $\begin{array}{l}\text { Poor information } \\
\text { dissemination/ } \\
\text { communication with the } \\
\text { public about disaster } \\
\text { victims. } \\
\text { It is unclear if the train } \\
\text { had a passenger list with } \\
\text { details of those onboard. }\end{array}$ & $\begin{array}{l}\text { Clear information and } \\
\text { communication channels } \\
\text { should be established to } \\
\text { inform the public about } \\
\text { disaster victims. } \\
\text { CAMRAIL should ensure } \\
\text { there is always a } \\
\text { passenger manifest for all } \\
\text { trains. }\end{array}$ \\
\hline & $\begin{array}{l}\text { Some passengers simply } \\
\text { 'disappeared,' and a few } \\
\text { dead bodies could not be } \\
\text { identified. }\end{array}$ & $\begin{array}{l}\text { Forensic techniques } \\
\text { should be used to identify } \\
\text { missing persons and/or } \\
\text { body parts after disasters. }\end{array}$ \\
\hline \multirow[t]{2}{*}{$\begin{array}{l}\text { Compensation for } \\
\text { Victims }\end{array}$} & $\begin{array}{l}\text { CAMRAIL and the } \\
\text { Government decided to } \\
\text { provide arbitrary } \\
\text { compensation to the } \\
\text { victims. } \\
\text { The compensation } \\
\text { amount is insufficient and } \\
\text { does not reflect the } \\
\text { injuries of victims. }\end{array}$ & $\begin{array}{l}\text { The government should } \\
\text { legislate a robust } \\
\text { compensation policy and } \\
\text { process for disasters in } \\
\text { the country. } \\
\text { The government should } \\
\text { intervene to protect } \\
\text { disaster victims if there is } \\
\text { evidence that they are } \\
\text { being exploited. }\end{array}$ \\
\hline & $\begin{array}{l}\text { Government pledged } \\
\text { compensation was } \\
\text { late-official list of } \\
\text { beneficiaries published } \\
\text { three years after the } \\
\text { incident. }\end{array}$ & $\begin{array}{l}\text { Financial assistance to } \\
\text { victims should be swift } \\
\text { because victims often } \\
\text { need urgent treatment } \\
\text { with implications for } \\
\text { their livelihoods. }\end{array}$ \\
\hline $\begin{array}{l}\text { Commission of } \\
\text { Enquiry (COE) }\end{array}$ & $\begin{array}{l}\text { Government 's COE was } \\
\text { under the auspices of the } \\
\text { PM. }\end{array}$ & $\begin{array}{l}\text { An independent COE } \\
\text { should have been created } \\
\text { considering the } \\
\text { government has stakes in } \\
\text { CAMRAIL. }\end{array}$ \\
\hline \multirow[t]{2}{*}{ Blame Avoidance } & $\begin{array}{l}\text { Both CAMRAIL and the } \\
\text { Government tried to } \\
\text { avoid blame and divert } \\
\text { culpability for the ETD }\end{array}$ & $\begin{array}{l}\text { Transport stakeholders } \\
\text { should acknowledge and } \\
\text { strive to correct mistakes } \\
\text { rather than engaging in } \\
\text { blame avoidance } \\
\text { measures. }\end{array}$ \\
\hline & $\begin{array}{l}\text { There were alleged } \\
\text { attempts both by the } \\
\text { government and } \\
\text { CAMRAIL to conceal } \\
\text { evidence that might } \\
\text { implicate them in the } \\
\text { accident. }\end{array}$ & $\begin{array}{l}\text { Attempts to conceal vital } \\
\text { evidence from disaster } \\
\text { scenes is a criminal } \\
\text { offence that should be } \\
\text { investigated, and the } \\
\text { culprits punished. }\end{array}$ \\
\hline \multirow[t]{2}{*}{$\begin{array}{l}\text { Implications for } \\
\text { CAMRAIL }\end{array}$} & $\begin{array}{l}\text { The Government planned } \\
\text { to review key aspects of } \\
\text { its rail transport } \\
\text { agreement with } \\
\text { CAMRAIL after the COE } \\
\text { findings. }\end{array}$ & $\begin{array}{l}\text { The actions suggested } \\
\text { should be speedily } \\
\text { implemented, enforced } \\
\text { and monitored on a } \\
\text { regular basis. Such } \\
\text { actions should not only be } \\
\text { taken after deadly train } \\
\text { crashes. }\end{array}$ \\
\hline & $\begin{array}{l}\text { The Government and } \\
\text { victims sued CAMRAIL to } \\
\text { get reasonable } \\
\text { compensation packages } \\
\text { for victims }\end{array}$ & $\begin{array}{l}\text { CAMRAIL should have a } \\
\text { robust compensation } \\
\text { policy and reasonable } \\
\text { budget to compensate its } \\
\text { customers when such } \\
\text { incidents occur. }\end{array}$ \\
\hline
\end{tabular}

Source: Authors 
independent COE should be government policy, enshrined in legislation, rather than at the discretion of the government. In fact, those commissioning an inquiry (independent or not), should not be implicated in the matter to be investigated, should not be witnesses, should be at arm's length so as to ensure the integrity of the investigation and should not be in a position to be put under improper pressure [69]. The COE into the ETD did not meet these criteria, hence the blame apportioned to one party in the concession is arguably, unjust. Only by commissioning an independent enquiry can the parties involve in a concession take full responsibility for their actions, resolve disputes and work in an atmosphere of mutual trust, including with the public.

Attempts to publicly avoid and divert culpability for the accident by both the government and CAMRAIL shows a sense of irresponsibility and mutual distrust between the partners. This may have implications for future cooperation because it might lead to an opaque environment where neither party feels comfortable to disclose factual information about their respective challenges [4], which is vital for the successful operation of a concession railway model.

The alleged intervention of the Minister of Transport to increase passenger traffic prior to the ETD was ill-conceived. Although the Ministry of Transport is the political authority responsible for transport services, responsibility for passenger operations lies with CAMRAIL [4]. The Minister's intervention could be attributed to mistrust in CAMRAIL, inexperience in the railway sector and how to manage passenger overflow. The safety issues mentioned in the COE's report could be attributed to CAMRAIL's weak/poor operational service management.

The comments in the COE's report that: "the response of the emergency services was inadequate and/or poor," confirmed the findings of this research and could be associated to communication and coordination resistance factors in Cameroons DM system [70]. The chaotic post ETD emergency management that was dominated by ad-hoc decisions reveals the challenges inherent in Cameroon's emergency management operations. Incident management activities like DVI and casualty tracking are yet to be fully addressed in DM policies.

The government has established an emergency relief fund [71], yet it took almost a year for the potential beneficiaries of the ETD to be identified [44] and recently, on August 2, 2019, the PM's office published the final official list of beneficiaries, three years after the ETD [72]. Delay in providing financial assistance to victims makes the service not fit for purpose and ineffective since most victims are rendered destitute while waiting for too long. Similarly, CAMRAIL provided an arbitrary compensation because there is no enforceable government legislative provision for victims of accidents. Considering the needs of victims, vulnerability to technological hazards should not play second fiddle in DRR policies, plans and resilience strategies. The decision to sack and replace CAMRAIL's top management following the ETD could be attributed to operational incompetence and misappropriation of funds.

The ETD demonstrates the perils on Cameroon's railways, which is laggards and atrophied and can be attributed to resistance factors in Cameroon's DRR framework including weak legislative structures/capacities [8]. The lack of adequate resources for DRR [70] entails a reactive crisis management model compromising safety and leading to technological hazards. Indeed, DRR should be incorporated in the daily decision making of organisations, companies, civil society and governments to achieve sustainable development [15]. Though a signatory to the SFDRR, there is little evidence of progress in Cameroon's DRR initiatives.

The challenges in Cameroon's railway sector could have consequences for road transportation. The unsafe railway network, we would argue, is contributing to the deteriorating road condition because of the increasing migration from rail to road-unfriendly traffic by big trucks carrying heavy goods and sustaining heavy traffic. A good railway management service will not only reduce rail inefficiencies, fatalities and cost, but also have a positive effect on road transport.

The response of the government to the ETD demonstrates that the political agendas in the railway sector seem to be dominated by shortterm urgencies, rather than a comprehensive and strategic overhaul of the sector. If the decisions taken by the government and CAMRAIL following the ETD are implemented, rail operations can improve in the short-term. Nevertheless, a robust regulatory and institutional framework for risk reduction, particularly a tightly regulated railway transportation sector would be necessary to mitigate contemporary and emerging risks/mishaps in the long-term. That would also save scarce resources spent on poorly executed response and recovery operations. Train crashes have persisted in Cameroon because the stakeholders have failed to fully exploit railway's modern technologies, making safety unsustainable and elusive.

For CAMRAIL to keep a solid reputation, as well as maintain reliability standards and safe-guard human life, the regulatory/institutional framework, infrastructure improvement, better maintenance and operational tactics should be improved.

This research is just the tip of an iceberg considering the numerous train crashes that occur in Cameroon and the existence of several resistance factors in Cameroons' disaster management system that post challenges for effective DRR and response [70]. As mentioned earlier, the EM-DAT/CRED database does not show an accurate picture of technological hazards (including train crashes) in Cameroon. In fact, a high frequency of train crashes occur every year with potentially dire ramifications for the victims but are rarely captured in academic research. Hopefully, this article will rejuvenate research interest in technological, social and intentional hazards/disasters in Cameroon and Africa.

\section{Conclusion and recommendations}

This article has analysed the management of the ETD that occurred on October 21, 2016 in Cameroon, considered the worst ever in the country. Although Cameroon's DM system is accustomed to responding to disasters and/or major incidents, the research findings have unveiled gaps in the response and recovery operations following the ETD. Findings indicate that CAMRAIL could not cognitively assess and review its operations when inundated with passengers due to road transport disruption. The management made poor operational decisions that eventually caused the ETD although remote causes associated with safety practices are also to be blamed.

The response to the ETD was unsatisfactory. Limitations have been identified in standard response activities such as crisis incident management, search and rescue, emergency treatment, evacuation of the sick/death, DVI and casualty tracking. Indeed, emergency training and conducting emergency drills is extremely limited or absent. We would argue that a well-resourced and trained emergency services with regular incident response drills is vital to improve response to technological hazards and disasters in Cameroons.

The study is also wary of the recovery practices, particularly concerning compensation for victims, which is not only inadequate, but delayed. In a country where life and/or property insurance is very limited, appropriate DM policies on compensation for disaster victims is invaluable to enhance and facilitate disaster recovery. More detailed recommendations on improving the response and recovery to the ETD and consequently technological disasters in Cameroon with implications for other developing countries are provided in Table 2. The recommendations show that improvements are needed in the response operations like search and rescue, provision of medical assistance, evacuation, mass casualty handling, DVI and general incident management.

This research has shown that railway service in Cameroon seems not to fit expectations. While the challenges involving the management of train accidents in Cameroon has yet to be quantified, the need for indepth investigation into the matter is required in order to provide realistic and pragmatic solutions. Therefore, further research to understand how disaster risk reduction and response can mitigate railway 
accidents and enhance customer confidence in Cameroon's railway transportation sector is needed.

\section{Declaration of competing interest}

None.

\section{Appendix A. Supplementary data}

Supplementary data to this article can be found online at https://doi. org/10.1016/j.ijdrr.2019.101410.

\section{References}

[1] EM-DAT/CRED, The Emergency Events Database: Centre for Research on the Epidemiology of Disasters, Brussels, Belgium, 2018. available at: http://www. emdat.be/. (Accessed 23 January 2019).

[2] R. Forsberg, U. Bjornstig, One hundred years of railway disasters and recent trends, Prehospital Disaster Med. 26 (5) (2011) 367-373, https://doi.org/10.1017/ S1049023X1100639X.

[3] World Bank, Railway Reform: Toolkit for Improving Rail, World Bank Group, Washington, D.C., 2011 available at: http://documents.worldbank.org/curated/e n/529921469672181559/Railway-reform-Toolkit-for-improving-rail. (Accessed 28 June 2018).

[4] ADB, Rail Infrastructure in Africa, Financing policy options, available at: https ://www.afdb.org/fileadmin/uploads/afdb/Documents/Events/ATFforum/ Rail_Infrastructure_in_Africa__Financing_Policy_Options___AfDB.pdf, 2015. (Accessed 11 April 2019).

[5] M. Mc Naught, C. Fourie, A review of critical problems from the desks of chief executive officers in the passenger railway service industry, WIT Trans. Built Environ. 146 (2015) 411-421, https://doi.org/10.2495/UT150331.

[6] I. Dambuza, An overview of the factors associated with driver distraction and inattention within the South African railway industry, in: N. Stanton, S. Landry, G. Bucchianico, A. Vallicelli (Eds.), Advances in Human Aspects of Transportation, Advances in Intelligent Systems and Computing, vol. 484, Springer, Cham, 2017, https://doi.org/10.1007/978-3-319-41682-3_6.

[7] UNEP, Awareness and Preparedness for Emergencies at Local Level: A Process for Improving Community Awareness and Preparedness for Technological Hazards and Environmental Emergencies, second ed., United Nations Environmental Programme, 2015 available at: https://www.unenvironment.org/ru/node/661. (Accessed 24 March 2019).

[8] H. Bang, General overview of the disaster management framework in Cameroon, Disasters 38 (3) (2014) 562-586, https://doi.org/10.1111/disa.12061.

[9] World Bank, Safer Homes, Stronger Communities: A Handbook for Reconstructing after Natural Disasters, 2010 available at: http://www.gfdrr.org/sites/gfdrr. org/files/Disaster_Types_and-Impacts.pdf. (Accessed 2 January 2019).

[10] L.K. Comfort, LK, Crisis management in hindsight: cognition, communication, coordination and control, Public Adm. Rev. 67 (Special Issue) (2007) 189-197, https://doi.org/10.1111/j.1540-6210.2007.00827.x.

[11] UN/ISDR, Man-made and Technological Hazards: Practical Considerations for Addressing Man-Made and Technological Hazards in Disaster Risk Reduction, 2018 available at: http://www.unisdr.org/files/54012_manmadetechhazards.pdf. (Accessed 9 February 2019).

[12] BTL, Bollore Railways, Concessions, CAMRAIL, 2015 available at: http://www.boll ore-transport-logistics.com/en/business-lines/bollore-railways/bollore-railways -concessions.html. (Accessed 2 April 2018).

[13] M. Hennick, I. Hutter, A. Bailey, Qualitative Research Methods, Sage, London, 2011.

[14] M. Pathranarakul, An integrated approach to natural disaster management, Disaster Prev. Manag. 15 (3) (2006) 396-413, https://doi.org/10.1108/ 09653560610669882.

[15] UN/ISDR, Sendai Framework for Disaster Risk Reduction 2015-2030, United Nations Office for Disaster Risk Reduction, Geneva, Switzerland, 2015 available at: http://www.unisdr.org/files/43291_sendaiframeworkfordrren.pdf. (Accessed 28 November 2018).

[16] D. Alexander, How to Write and Emergency Plan, Dunedin Academic Press, 2016.

[17] S. Richter, E. Heumuller, U. Lechner, Concepts for Command and Control Effectiveness in German Disaster Response, 2010 available at: https://domino.fov. uni-mb.si/proceedings.

nsf/0/73f44e0184580b91c1257757003d0661/\$FILE/28_Richter.pdf. (Accessed 13 December 2018)

[18] G. Haddow, J. J Bullock, Introduction to Emergency Management, Elsevier Science and Technology, Oxford, UK, 2014.

[19] P. Aitken, P. Leggat, Considerations in Mass Casualty and Disaster Management, 2012 available at: https://cdn.intechopen.com/pdfs-wm/31947.pdf. (Accessed 15 August 2018).

[20] A. Boin, Thinking the unthinkable: the limits of traditional crisis management and the necessity for new approaches, first OECD/Swiss federal chancellery workshop on strategic crisis management, Geneva, June 28, 2012, available at: https://slide player.com/slide/704676/. (Accessed 23 January 2019).

[21] N. Mueller, Proposition for a multi-dimensional, integrated approach for a crisis management system on a national level, in: 14th Annual Conference of the
International Research Society for Public Management Conference, Berne, 2010 available at: https://www.researchgate.net/publication/270480513 Propositio n_for_a_multi-dimensional_integrated_approach_for_a_crisis_management_system_o n_a_national_level. (Accessed 12 March 2018).

[22] D. Beckett, National Response and Disaster Recovery Frameworks, Nova Science Publishers Inc, 2014.

[23] UK Cabinet Office, Responding to Emergencies, UK Central Gov Response Concepts of Operations, 2013 available at: https://www.gov.uk/government/uploads/syste m/uploads/attachment_data/file/192425/CONOPs_incl_revised_chapter_24_A pr-13.pdf. (Accessed 17 May 2017).

[24] M. Hargrow, Creating conditions for survivor's recovery from natural and manmade disasters, J. Black Psychol. 39 (3) (2013) 248-251, https://doi.org/10.1177/ 0095798413480672.

[25] P. Gardoni, C. Murphy, Recovery from natural and man-made disasters as capabilities restoration and enhancement, Int. J. Sustain. Dev. Plan. 3 (4) (2008) 1-17, https://doi.org/10.2495/sdp-v3-n4-317-333.

[26] E. de Guzman, Towards Total Disaster Risk Management Approach, Asian Disaster Reduction Centre. Japan: ADRC, 2013 available at: http://unpan1.un.org/intrad oc/groups/public/documents/APCITY/UNPAN009657.pdf. (Accessed 9 February 2019).

[27] UN/ISDR, Terminology, 2009 available at: https://www.unisdr.org/we/inform/te rminology. (Accessed 10 December 2018).

[28] A. Bhattacherjee, Social Science Research: Principles, Methods, and Principles, $2^{\text {nd }}$ ed., Create Space Independent Publishing Platform, Tampa, Florida, 2012.

[29] S. Soy, The Case Study as a Research Method, 2006. Texas, USA.

[30] MINSANTE, Situation Report No 01, Derailment of a Train at Eseka on 21 October 2016, Ministry of Public Health, Cameroon, 2016 available at: https://www. humanitarianresponse.info/system/files/documents/files/sitrep_2_deraillement_ du_train_a_Eseka_-_22_octobre_2016.pdf. (Accessed 1 June 2018).

[31] MINSANTE, Eseka District Hospital: MINSANTE in the Field, 2016 available at: http://www.minsante.cm/site/?q en/node/652. (Accessed 25 March 2018).

[32] MINSANTE, Railway Accident of 21 October 2016 in Eseka, 2016 available at: http: //www.minsante.cm/site/?q en/content/accident-ferroviaire-du-21-octobre-201 6-\%C3\%A0-es\%C3\%A9ka. (Accessed 13 April 2018).

[33] Presidency of the Republic of Cameroon, Eseka Train Accident: Statement by the Head of State, 2016. https://www.prc.cm/en/multimedia/documents/4825-de claration-de-se-paulbiya-accident-ferroviaire-d-Eseka-english. (Accessed 1 March 2018).

[34] Presidency of the Republic of Cameroon, Derailment at Eseka: the Head of State Disburses FCFA 1 Billion to Victims, 2017 available at: https://www.prc.cm/en/ news/press-releases/2274derailment-at-Eseka-measures-taken-by-the-head-of-st ate?highlight WyJlc2VrYSJd. (Accessed 25 March 2018).

[35] World Bank, Project Appraisal Document on a Proposed Credit in the Amount of SDR 17.20 Million (US\$ 21.39 Million Equivalent) to the Republic of Cameroon for a Railway Concession, 2002 available at: http://documents.banquemondiale.org /curated/fr/452631468743108314/pdf/multiopage.pdf. (Accessed 17 June 2017).

[36] IFRC, Emergency Plan of Action Cameroon: Train Crash. DREF No.MDRCMO24, 2016 available at: http://adore.ifrc.org/Download.aspx?FileId 151481. (Accessed 5 February 2018).

[37] CAMRAIL, Information Note-Douala on 24 May 2017, 2017. https://fr.africanews. com/2017/05/26/cameroun-accident-de-train-d-Eseka-la-camrail-contredit-le-ra pport-de-la/. (Accessed 9 April 2018).

[38] Nathan Associates INC, Logistics Cost Study of Transport Corridors in Central and West Africa, 2013 available at: https://www.ssatp.org/sites/ssatp/files/publicat ions/SSATP_Logistics_Cost_Study_Complete\%20with\%20annexes\%20Final\%20Se ptember\%202013.pdf. (Accessed 12 March 2019).

[39] I. Halloway, S. Wheeler, Qualitative Research in Nursing and Health Care, WileyBlackwell, Chichester, 2010.

[40] M. Coyne, Sampling in qualitative research. Purposeful and theoretical sampling; margin or clear boundaries? J. Adv. Nurs. 26 (1997) 623-630, https://doi.org/ 10.1046/j.1365-2648.1997.t01-25-00999.x.

[41] L. Finlay, Phenomenology for Therapists, Wiley-Blackwell, Chichester, 2011.

[42] A. Bryman, Social Research Methods, Oxford University Press, New York, 2008.

[43] P.J. Kouagheu, Cameroon: in Eseka, the Difficult Extraction of the Bodies of the Victims of the Train Accident, 2016. https://www.lemonde.fr/afrique/article/201 6/10/23/cameroun-a-esaka-la-difficile-extraction-des-corps-des-victimes-de-1-a ccident-de-train_5018895_3212.html. (Accessed 14 May 2017).

[44] Prime Minister's Office, Republic of Cameroon List of Persons Benefitting from the Financial Assistance by the Head of State to Victims of the Eseka Train Accident of 21 October 2017, 2017 available at: https://www.spm.gov.cm/site/sites/defaul t/files/LISTE\%20DES\%20VICTIMES\%20ESEKA_ENG.pdf. (Accessed 17 June 2018).

[45] News/Africa, Cameroon Train Crash: Scores Killed, Hundreds Injured, 2016 available at: https://www.aljazeera.com/news/2016/10/53-killed-cameroon-tra in-derailment-161021192603296.html. (Accessed 5 February 2017).

[46] A.B. Atabong, Cameroonians Are Furious with Their 'absent' President after a National Tragedy, 2016 available at: https://qz.com/africa/818654/cameroons-pa ul-biya-is-slammed-by-his-country-for-his-lukeware-reaction-to-the-Eseka-tra in-crash/. (Accessed 9 February 2017).

[47] Cameroon Concord, Lessons Government Must Learn as Land Transport Resume on Yaounde-Douala Highway, 2016 available at: http://cameroon-concord.com/e ditorial/lessons-gov-t-must-learn-as-land-transport-resumes-on-douala-Yaoundehighway. (Accessed 24 August 2017).

[48] Cameroon Intelligence Report, Yaounde-Douala Motorway Crisis Affecting the Entire Sub Sahara Region, 2016 available at: http://www.cameroonintelligencere 
port.com/douala-Yaounde-motorway-crisis-affecting-the-entire-sub-saharan-re gion/. (Accessed 4 July 2017).

[49] M.E. Kindzeka, Relatives Search for Victims of Deadly Cameroon Train Crash, 2016 available at: https://www.voanews.com/africa/relatives-search-victims-deadl y-cameroon-train-crash. (Accessed 12 March 2017).

[50] Le Figaro fr, Cameroon: a Frenchman Among the Victims of the Derailment of a Train, 2016 available at: http://www.lefigaro.fr/international/2016/10/21/01 003-20161021ARTFIG00403-cameroun-plusieurs-dizaines-de-morts-dans-le-dera illement-d-un-train.php. (Accessed 28 June 2017).

[51] 237 Online, Eseka Train Crash: what Philemon Yang Went to Do at Eseka, 2016. htt p://www.jobincameroun.com/conseils-candidats/3540-accident-du-train-d-Esekace-que-philemon-yang-est-alle-faire-a-Eseka.html. (Accessed 4 July 2017).

[52] MINSANTE, Train Accident: MINSANTE at the Bedside of the Victims, 2016 available at: http://www.minsante.cm/site/?q en/node/641. (Accessed 17 March 2017).

[53] E. Kouagne, Cameroon. Eseka Railway Tragedy: Polemics Around Compensation, 2017 available at: http://afrique.le360.ma/autres-pays/societe/2017/06/29/12 990-cameroun-tragedie-ferroviaire-dEseka-polemique-autour-des-indemnisations -12990. (Accessed 24 April 2018).

[54] 237Actucom, Cameroon-eseka Accident: Dorette Dissake Not Found One Year after the Disaster, 2017 available at: https://237actu.com/pid/633. (Accessed 9 June 2018).

[55] E. Kouagne, Cameroon: the Eseka Railway Catastrophe and its Mysterious Disappearances, 2017 available at: https://m.le360.ma/afrique/autres-pays/societ e/2017/09/13/14984-cameroun-la-catastrophe-ferroviaire-dEseka-et-ses-dis paritions-mysterieuses-14984. (Accessed 17 June 2018).

[56] J.M. Fogang, Cameroon: State Compensates Victims of Eseka Train Accident, 2017 available at: https://fr.blastingnews.com/international/2017/05/cameroun1ETDt-dedommage-les-victimes-de-laccident-de-train-dEseka-001722187.html. (Accessed 3 April 2018).

[57] Actu Cameroun, Cameroon: Eseka Train Accident, Compensation of Victims at the Center of a Controversy, 2017 available at: https://actucameroun.com/2017/08/ 31/cameroun-accident-du-train-dEseka-lindemnisation-des-victimes-au-centre-d une-polmique/. (Accessed 16 August 2018).

[58] L. Mbanga, Cameroon: Derailment in Eseka: A Railway Worker Threatened with Death, 2016. http://www.hurinews.com/cameroun-deraillement-dEseka-un-chemi not-menace-de-mort/. (Accessed 28 October 2017).

[59] F.N. Ngoh, Eseka Train Disaster: Biya Offers 1 Billion FCFA to Victims, Vindicates Transport Minister, 2017 available at: http://www.cameroonconcordnews.co $\mathrm{m} /$ Eseka-train-disaster-biya-offers-1-billion-fcfa-to-victims-vindicates-transportminister/. (Accessed 18 September 2018).

[60] Le Point International, Cameroon: 79 Dead in Yaounde-Douala Train Accident, 2016 available at: https://www.lepoint.fr/monde/cameroun-79-morts-dans-1-acci dent-du-train-Yaounde-douala-24-10-2016-2078120_24.php. (Accessed 21 April 2018).
[61] L. Miles, R. Gordon, H. Bang, Blaming active volcanoes or active volcanic blame? Volcanic crisis communication and blame management in the Cameroon, in: C. Fearnley, D. Bird, G. Jolly, K. Haynes, B. McGuire (Eds.), Observing the Volcano World, Volcanic Crisis Communication, Springer, Berlin, Heidelberg, 2017, https://doi.org/10.1007/11157_2017 2.

[62] J.B. Naudet, Railway Disaster in Cameroon: Two Complaints Filed against Bollore in France, 2017 available at: https://www.nouvelobs.com/monde/20170213. OBS5269/catastrophe-ferroviaire-au-cameroun-bollore-vise-par-deux-plaintes-enfrance.html. (Accessed 16 February 2018).

[63] C. Leon, Eseka Drama in Cameroon: Those Responsible Face Justice, 2017 available at: http://www.rfi.fr/afrique/20171110-drame-Eseka-cameroun-respo nsables-presumes-face-justice. (Accessed 20 February 2018).

[64] C. Kouassi, Cameroon - Eseka Train Accident: Camrail Disputes the Report of the Commission of Inquiry, 2017 available at: https://fr.africanews.com/2017/05/ 26/cameroun-accident-de-train-d-Eseka-la-camrail-contredit-le-rapport-de-la/. (Accessed 2 July 2018).

[65] Jobincameroun.com, Camrail Train Accident. After the Eseka Disaster, the State of Cameroon Obtains from Bollore the Division of Powers in the Top Management of Camrail, 2017 available at: http://www.jobincameroun.com/conseils-candidats /5116-accident-train-camrail-apres-la-catastrophe-d-Eseka-l-ETDt-camerou nais-obtient-de-bollore-le-partage-des-pouvoirs-dans-le-top-management-de-ca mrail.html. (Accessed 5 June 2018).

[66] International Railway Safety Council, Railway safety, available at: https://internat ional-railway-safety-council.com/safety-statistics/, 2018. (Accessed 14 June 2019).

[67] R. Rautji, T.D. Dogra, Rail traffic accidents: a retrospective study, Med. Sci. Law 44 (1) (2004) 67-70, https://doi.org/10.1258/rsmmsl.44.1.67.

[68] A.W. Evans, Accidental fatalities in transport, J. R. Stat. Soc. A 166 (2) (2003) 253-260, https://doi.org/10.1111/1467-985X.00274.

[69] M. Smith, A Practical Guide to Commissioning and Conducting Investigations and Inquiries, 2008 available at: https://www.fieldfisher.com/publications/2008/ 12/a-practical-guide-to-commissioning-and-conducting-investigationsand-inquiries\#2. (Accessed 21 October 2019).

[70] H.N. Bang, L. Miles, R. Gordon, Disaster Risk Reduction in Cameroon: Are Contemporary Disaster Management Frameworks Accommodating the Sendai Framework Agenda 2013?, 2019, https://doi.org/10.1007/s13753-019-00238-w.

[71] MINATD/DPC, Cameroon Civil Protection Report, 2008/2009: Civil Defense through Life-Saving Actions, 2009 available at: https://www.preventionweb.net/fi les/10253_MicrosoftWord10242CameroonCivilProt.pdf. (Accessed 21 February 2015).

[72] E. Tataw, Cameroon Government Ridicules Self, Publishes Eseka Train Accident Victims' List 3 Years after, 2019 available at: https://nationaltelegraph.net/camer oon-government-ridicules-self-publishes-eseka-train-accident-victims-list-3years-after/. (Accessed 15 September 2019). 